\title{
A case for consonance between science and theology: The cosmological Christ as the scriptural and confessional focal point for dialogue
}

\author{
Pieterse, André C \\ University of the Free State ${ }^{1}$ \\ andre@caw.org.za
}

\begin{abstract}
The purpose of this article is to prove through theological reasoning why consonance between the sciences is biblically, as well as confessional sound. The substance for the argument is found in the Biblical confessions regarding Christ, as well as God's Trinitarian agency in the cosmos. The insight that Christ is God incarnated, the King, Creator and Redeemer of the entire cosmos, have important implications for the current dialogue between the sciences. An analysis of the relevant texts and historical confessions should prove that nothing in creation, including scientific endeavour, could be excluded from Christ's interaction with creation. The Cosmological Christ is the Scriptural and confessional focal point for dialogue and consonance between the sciences.
\end{abstract}

Key words

Consonance; cosmology; God's agency; science and religion; Cosmic Christ

\section{Introduction}

One would assume that in a modern/postmodern society with its tendency of tolerance the debate between the sciences should be settled. Despite this rhetoric of progressiveness, the relationship between the sciences is still unclear. Scholars from different paradigms still hold true to the perceived notion that conflict or separation is the only possible connection between theology and the natural sciences. For example, (Horgan 2005) reminds us of the so called 'Clash in Cambridge' in 2005 during the Templeton-

1 André Pieterse is a research associate at the University of the Free State (UFS). 
Cambridge Journalism Fellowship where Richard Dawkins as a proponent of modern atheism forcefully made this view clear. He argued that from an epistemological, as well as a philosophical point of view, the sciences are irreconcilable. It is also the opinion of Worrall (2004: 60) when he states that: 'There is no way in which you can be both properly scientifically minded and a true religious believer'. This notion of conflict or separation is still prevalent today within, or among evangelical Christians in the United States as (Gannon 2015) points out. The question remains, are conflict or separation the only reasonable option for dialogue between the sciences? I will argue, absolutely not! Consonance is not only possible, but a necessity from a Biblical, theological and confessional point of view. In order to follow the line of thought it is necessary to first take a brief introductory detour regarding the different nuances which influence the comprehension of consonance. The first of these challenges is to be certain what precisely is the intended meaning of the word in this context and its relationship to the broader debate.

\section{Semantic challenges vis-à-vis consonance}

The complexities within theology and natural science as individual disciplines naturally leads to different opinions regarding their relationship to one other. Barbour's (1990) classic fourfold model of conflict, independence, dialogue and integration gives a broad understanding of the dilemmas faced in the ongoing debate. Stenmark ${ }^{2}$ and Haught ${ }^{3}$ employs different methods, whereas Polkinghorne (2004:9) redefines Barbour's proposal of dialogue and integration, into consonance and assimilation. The premise of this article guides one to favour Polkinghorne's opinion and his use of consonance. What does he mean when he speaks of a consonant relationship between the sciences (1996b:6-7)? Fulljames and Stolberg (2000:36) defines Polkinghorne's use of the phrase as, '...a search for mutual consistency between disciplines whose separate identities are to be respected, and this is expected to be 'not as a mere matter of compatibility but with a degree of mutual enhancement and enlightenment'. In

2 Stenmark $(2010: 278,279)$ differentiates between (1) irreconcilability; (2) reconciliation, (3) independence; (4) replacement.

3 Haught (1995) prefers to speak of conflict, contrast, contact, and confirmation. 
contrast, assimilation ${ }^{4}$ (describes) 'more merging of the two disciplines' so that although one is not absorbed by the other there may well be 'some accommodation of one to the other'. Thus, there is a systematic interaction between the two'.

One of the many challenges within the current debate between the sciences is the role semantics play in clarifying certain phrases. Often scholars use the same word, but their understanding thereof and its application differ. This is also true when one reflects on the meaning of consonance. For example, Polkinghorne understands consonance as a respectful dialogue between equal partners and beneficial to all the parties involved. Peters ${ }^{5}$ expands on this assessment, although he favours the term Hypothetical consonance (1997:652). In contrast, some theologians believe that consonance's only aim is for theology to align herself regularly with scientific understanding (Southgate 1999). In this sense theology always plays second fiddle to natural science. This is not the application or understanding of consonance within this article. The quest for consonance could inherently be dangerous for theology and science when the boundaries Polkinghorne highlights are disregarded.

What is the possible threats for theology if the equal status of the sciences is abandoned? One example is the doctrine of creationism. Conversely, for natural science, an ideology like scientific imperialism (Peters 1997:650) is not beneficial, or a reflection of proper scientific method. Both ideas could be detrimentally linked to consonance.

The concept of creationism $^{6}$ is important for many evangelical Christians because it recognizes the work of a Creator God regarding all of creation. Lennox (2007:11) points out that this initial meaning was distorted and expanded, and it led to diverse meanings within certain debates. For

4 Haught (1995:14) prefers the term conflation and warn against the fusion of science and religion because it obscures any real relationship between them.

5 'Consonance' in the strong sense means accord, harmony. Accord or harmony might be a treasure we hope to find, but we have not found it yet. Where we find ourselves now is working with consonance in a weak sense - that is - by identifying common domains of question-asking' (Peters 1997:652).

6 Creationism (2017): 'a doctrine or theory holding that matter, the various forms of life, and the world were created by God out of nothing and usually in the way described in Genesis'. 
example, creationism became associated with a specific interpretation of Genesis which holds that the earth is only a few thousand years old. In addition, science now has the dubious task of validating this biblical 'evidence'. In a sense, a certain consonance is created between the sciences. However, the big problem with this line of thought is: Faith looks to science for validation! When a new scientific hypothesis arises (frequently) and the Biblical 'evidence' is threatened, faith is being questioned!

Another misinterpretation of consonance could also be hazardous to natural science. Haught $(2012: 25,26)$ deliberates over the assumption of certain scientists, like Stephen Hawking ${ }^{7}$, that science per se is the only true custodian of all knowledge. This type of argument leads to specific philosophical constructions e.g. Scientific imperialism (Peters 1997:651), scientific naturalism, and reductionism, all of which relies on a very limited view of creation, which in turn is detrimental to the very essence of scientific endeavour. Why? Because true science is interested in all possible knowledge about a certain entity, especially if the entity (e.g. the cosmos itself) is complex in nature and includes different dimensions! In this case the notion that natural science could explain everything in the cosmos given enough time leads to confusion. The problem with this argument is the belief that, whatever religion says could be explained by scientific endeavour. Eventually a certain consonance transpires between science and religion, but only because science provided insight and a complete comprehension of the spiritual dimension. A dimension which it turns out (according to scientism) was nothing more than the interaction of physical processes ${ }^{8}$. This perception looks primarily to the research done in the neuro-sciences for its validation. This absolutism of natural science is scientifically and philosophically flawed and ironically unscientific (Pieterse 2015:2,11).

7 In his deconstruction of scientism, (Hughes 2012), allude to Hawking and Mlodinow's opening statement in their work, The Grand Design (2010) where it is stated: 'What is the nature of reality? Where did all this come from? Did the universe need a creator? Traditionally these are questions for philosophy, but philosophy is dead. Philosophy has not kept up with modern developments in science, particularly physics. Scientists have become the bearers of the torch of discovery in our quest for knowledge' (Hawking and Mlodinow 2010:5).

8 Peters (1997:650) recalls the work of Tipler (1994: ix,10,17,247) who argued that scientific knowledge (e.g. about quantum theory, the Big Bang hypothesis, and thermodynamics) could explain the future resurrection of the dead better than Christianity. 
If the above-mentioned pitfalls, as well as the semantics regarding the use of consonance are kept in mind the purpose of this article could then be stated as: An attempt to prove through theological reasoning why consonance between the sciences is biblically, as well as confessional sound. This argument is necessary because it emphasizes that consonance between different aspects in creation is not motivated by the recent scientific struggle to unite all the properties in the universe (e.g. Barrow 2007), but that consonance is possible only because all of creation is part of the ongoing work of the triune God. These insights could be valuable to believers who uphold the authority of Scripture, but tend to misunderstand the relationship between faith and science - or is disillusioned or threatened by science. Alternatively, non-Christian scientists could find these arguments (founded on Scriptural authority) enlightening, especially if they understand that epistemologically, theology and natural science ${ }^{9}$ have much in common.

The premise of this article is that the Biblical confession regarding Christ as stated in the New Testament (e.g. Colossians 1, John 1) has important implications for the current dialogue between the sciences. Paul reminds us in Colossians 1:15-20 that Christ is not only the Redeemer of the soul, but that He is God incarnated, the King, Creator and Sustainer of the entire cosmos. Redemption has cosmological implications and that nothing, including scientific endeavour, could be excluded from Christ's interaction with creation. Thus, the title of the article: A case for consonance between science and theology: The Cosmological Christ as the Scriptural and confessional focal point for dialogue.

If the Christian believer/theologian takes this confession of the cosmological Christ's kingship over all of creation seriously there must be a certain consonance between the two 'stories' (Biblical and scientific) ${ }^{10}$ of creation. Why? Because, there is an ongoing process of God's revelation through Scripture and responsible complementary scientific endeavour

9 Although there are distinct methodological differences between theology and natural science (e.g. in the way empirical research is conducted), Van Huyssteen (1998:49) explores the possibility of a holistic epistemology where science and religion find common ground in their quest for knowledge within one reality. Polkinghorne (1996c:31; 2004:37) develops this argument further and draws attention to a common rationality between the sciences, as well as methodological similarities.

10 Consonance according to the contrast and independence viewpoints is a fallacy. Therefore they speak of more than one 'story' in creation. 
(Pieterse 2015). Contemporary scholars e.g. Polkinghorne (1987:54); Conradie (2009:7) and Gunton (2002:193) are contented to connect the triune God's interaction with creation not only in a spiritual sense, but through a physical presence in the person of the Holy Spirit ${ }^{11}$.

The quest for consonance is imperative for several reasons. (1.) Theology and natural science study and address the same reality of which Christ is King. The importance of this insight leads Pannenberg (1994:60) to conclude that, if it is not accepted, it is equal to a conceptual failure of confessing the deity of the God of the Bible. (2.) The belief of the early church in a triune Creator (una substantia tres personae) and subsequent confession thereof through the ages emphasizes the personhood of God. Therefore, God's agency in the world is not the result of an impersonal action, but emerges from personal involvement. God's being and God's actions are thus relationally connected. Consequently, Polkinghorne (1996a:243) concludes that the triune God views creation in a holistic manner as Job 40:15 testifies. Consonance therefor is a natural extension within a cosmos that is relationally connected to itself and its Creator. (3.) In Gen 1:28 God instructs man (which was created in His image) not only to procreate, but reminds him of his responsibility towards nature. Van

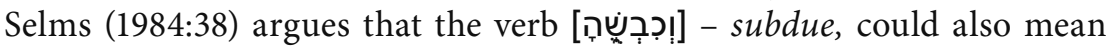
that man has an obligation to rule responsibly over creation in such a way that everything in nature are aligned to serve God and extends His glory. The practical implementation of this command certainly includes then, not only the studying of God's Word, but also the exploration of nature and the cosmos by means of man's ability to employ logic and rationality. In this sense, the quest for consonance between the sciences lay in their dual purpose to serve the creator, albeit with different methodologies.

I believe ongoing dialogue regarding consonance is a necessity for the natural sciences as well as for theology. This article could make a valuable contribution in this regard. Although the Scriptural confession concerning Christ's cosmological relevance is primarily a statement grounded in faith, it also has important scientific implications. For example, it presents an

11 This presence of God in creation should not be confused with the pantheistic paradigm where Creator and creation are intertwined in such a way that creation itself becomes divine. 
alternative option in the pursuit of finding a possible theory of everything ${ }^{12}$ which exclusively seeks a scientific answer. For believers, Christ is not a theory. He is the second Person within the trinity, the Creator and Sustainer of everything as Colossians 1 reminds us. For the Christian scientist, this reality could possibly open new avenues of reflection. Conversely, for those believers within the Kingdom who struggle to visualize the notion that scientific endeavour could be mutually beneficial to faith bounded beliefs, this Scriptural and confessional argument could enlighten their perspective.

To explain the significance of the cosmological Christ within the science and religion debate, I will structure the argument in the following manner: It is important to clarify Scriptures' perspective, if any, regarding the concept of consonance. Therefore, one must make a few introductory comments about different approaches to the exegesis of Scripture. Secondly, certain Old Testament texts, and their view on the unity in creation will be examined. Thirdly, it is necessary to investigate the meaning of the Cosmic Christ in the New Testament, and possible implications for the debate between the sciences. Finally, a few thoughts on the articles of faith and their view on consonance is appropriate.

The author, as a believer in the triune God, understands Scripture as God's revelation of Himself to the world. This revelation encompasses more than mere spiritual issues. Scripture also speaks with authority regarding the nature and purpose of the physical universe (Pieterse 2015:1.) Therefore, the author believes that a Complementary convergent approach ${ }^{13}$ to the sciences might be useful in, (i) the grand debate relating to theology's role in an ever-expanding scientific landscape, and (ii) to the relevance of the cosmological Christ with regarding to consonance between the sciences.

In addition, the authoritative nature of Scripture within the grand debate should also be emphasised. The arguments in this article with relation to Christ's identity relies on Scriptural references. The question may be,

12 See Barrow 2007.

13 Pieterse 2015; Haught (2012:4,5): 'A convergent approach concurs with the contrast method that religious faith and natural science are two distinct ways of understanding the world, but it acknowledges that they inevitably interact. It proposes that scientific data can broaden the scope of Scriptural understanding. Likewise, Biblical faith could deepen the meaning of scientific discoveries.' 
does the quoting of biblical texts assist theologians and scientists (in latemodern times) in their dialogue with other fields of inquiry? Absolutely! Methodologically this article wants to affirm the principle that theology should be respected as an equal partner in the debate with natural science. This statement is a point of contention within the ongoing debate, especially regarding to methodological and empirical differences between the sciences. Yet, compelling arguments to confirm this statement are well documented ${ }^{14}$. Apart from shared epistemological foundations (as previously cited), a leading scholar like (McGrath 2004:257) concludes: 'Theology like the natural sciences is thus to be seen as an, a posteriori discipline, shaped by its distinctive objects, rather than predetermined patterns of human thought'. He argues that theology should bring its thoughts and ideas into line with God's revelation in Scripture. This appeal to Divine revelation is by no means inferior to any scientific hypothesis.

The author accepts that the use of various Biblical texts in the conclusion of certain arguments is by no means a simplistic matter. The author is deeply conscious of the complexity of these texts in their divergent contexts. Unfortunately, it is not within the scope of this work to deal with each text and its peculiarities on an individual basis. The authors own approach to the different texts and traditions could be described as a historical-literary method whereby the unique context and literary type, as well as, the ecumenical tradition regarding Scriptural references are acknowledged. Any text has relevance for the initial readers in the first place, but as God's Word to the church of all ages, the text is also significant and transformational through the illumination of the Spirit in any time.

\section{Scripture and consonance}

\section{Different models of exegesis, preferences and reasons}

As believers, we confess that the Holy Spirit not only reveals, but also illuminates Scripture for us to understand the full implications of the revelatory Word. However, it is also important to remember that any

14 For example, Torrance (1969:281-2): '(Theology is a)... unique science devoted to knowledge of God...(and) which can be apprehended only on its own terms...' In the debate between the sciences, theology and natural science are equals, as long as their unique attributes are mutually respected; Polkinghorne 2005:43; Gerhart \& Russel (1996:125). 
interaction with Scripture includes the human element of interpretation. One of the attributes of being human is the ability to have a subjective opinion on reality which is embedded in specific preconceived assumptions. The fallacy of absolute objectivity has been effectively dealt with by numerous scholars e.g. Popper (2002), Wolterstorff (1988). Through the ages there has been several models ${ }^{15}$ that believers utilized to better grasp the full implications of the Word. It is not within the scope of this article to do an in-depth analysis of each method, although it is important to realize that any Scriptural references in this, and any other article, are subject to a specific analysis and interpretation of the Word by a commentator.

\section{The Old Testament and the unity in creation}

In the OT, the concept of consonance is obviously not mentioned or even inferred in the Scriptural confessions about Gods interaction with man or creation. Yet, there is ample evidence of a harmonious interface in creation regarding the material and spiritual realms. It becomes clear that historical ${ }^{16}$, as well as current dualisms ${ }^{17}$ regarding God, man and nature are strange to OT Scriptures. Childs $(1985: 178,182)$ for example confirms that the covenant people (Israel) had no clear separation between civil, legal, military and religious spheres of life. The triune God as the Creator and Sustainer of all creation cannot be reduced to a mere cultic presence. As an immanent God His will and guidance embrace every faculty of creation, while His transcendence reminds us that He remains distinctly different and separate from nature. This same inclusive awareness of God's encompassing commitment is evident throughout Old Testament Scriptures. For example, the two creation narratives in Genesis 1 and 2 relates that in beginning God created man in His image from the dust of the earth (material), and 'breathed life-giving breath into his nostrils and

15 See Biblical Exegesis: An Introductory Overview - http://catholic-resources.org/Bible/Exegesis. htm

16 In his analysis of Bavinck's theology, Veenhof (2006) states: 'Catholicism, therefore, holds to a "juxtaposition" of the natural and the supernatural order.' Thus, 'The supernatural is an order of its own, aloof from the natural life, and sealed off from it on all sides.' In recent times, this traditional strict dualism between grace and nature is being reviewed within certain Catholic circles.

17 Conflict or separation are two possibilities to define the relationship between theology and science. Unfortunately, both methods at their very core assume that the material and spiritual realms are not compatible. 
man began to live' (spiritual) (Holy Bible 1991). The essence of man was supposed to represent the triune God, and God revealed Himself within every aspect of life. As Wright (2011) eloquently puts it: 'God's sphere and our sphere - are not thought of as detached or separate. They overlap and interlock. God is always at work in the world, and God is always at work in, and addressing, human beings, not only through one faculty such as the soul or spirit but through every fibre of our beings, not least our bodies.'

What then is the significance regarding consonance? Biblical confession states that from the very beginning the Creator is actively involved in His creation. Creation and providence cannot be separated. Naturally then, any analysis of nature or the cosmos must take note of God's unique presence. Scientific enquiry and religious confession are both connected through the triune God's pledge to creation. Conversely, if any research is attempted where science is the only sure way to true knowledge (scientism) and faithful confession are ridiculed, consonance remains a bridge too far.

\section{Cosmology and the Old Testament}

When one reflects on the concept of consonance, specifically from an Old Testament perspective, it is important to follow the way cosmology is understood and utilized within Old Testament theology ${ }^{18}$. The scope of this article prevents the author from a detailed analysis of this important concept in the Old Testament. However, a few introductory remarks are necessary. Kärkkäinen $(2015: 17,18)$ states that the Old Testament does not discuss cosmology as topic, separate e.g. from the creation of man, or eschatological fulfilment. Nature is predominantly a subject to a broader spiritual message. Creation is depicted as an orderly cosmos brought about and controlled by Yahweh. Any knowledge about creation is mediated by God, for example Solomon's wisdom in 1 Kings 5:10-14. There is a bond between man and creation, and God as the Creator and Sustainer of both, are the One whose caring and wisdom forms the foundation of this intertwined relationship. Fergusson (2010) detects evidence of this interrelatedness between God and His creation in the calling of Abraham

18 Any theology is temporal in nature and subject to interpretations, (e.g. Waltke 2007). The Old Testament is also a collection of different traditions (Zion, prophetic etc.) each of which has a certain emphasis. Old Testament theology in this context refers to main stream views and subject to peer review. 
(Genesis 12:1-3). Gods covenantal blessing, '... is expressed, moreover, through a system in which all creatures are interrelated in a cosmic whole. God does not relate to us merely as individuals but as persons who exist in relation to one another and to the wider environment' (Fergusson 2010). Is it possible to see glimpses of consonance in God's interaction with Abraham? Definitely. The agency of the triune God unites man and creation into a common destiny. This destiny has an eschatological purpose.

In his article, Cosmological and Biblical eschatologies: Consonance or dissonance, Ferreira (2003:309-313) reflects on the way an initial corporate eschatology in the Old Testament transformed into a cosmic eschatology. He states, 'At first the future is described in terms of the common destiny of the nation (e.g. Gen $3: 15 ; 12: 1-3$ ), individual identity was a foreign concept. This corporate eschatology develops into a cosmic eschatology (Isaiah $11: 6-9 ; 40: 3-4 ; 41: 18-20)$, although the people always stand at the centre' (Ferreira 2003:309). The meaning of a cosmic eschatology becomes clearer in Isaiah 65:17 where the author speaks of a new creation, more specifically 'the new heavens and the new earth' (Ferreira 2003:313). This transition comes about solely through Yahweh's action alone. Deist and Vorster (1987:162) elaborates further on this gradual shift in focus and the cosmic implications of the apocalyptic prophesies in the Old Testament (e.g. Isaiah 24-27, 56-66; Zechariah 9-14). The presence of a cosmic eschatology in the Old Testament is important for various reasons.

Firstly, it reminds us that the confession in Colossians 1 where Jesus is revealed as the cosmic Christ, is not unique to the New Testament. Although the first receivers of Isaiah's prophecy did not know what we, and the believers in the New Testament confess about Christ, retrospectively it becomes clear that Jesus as God incarnated was from the very beginning the focal point of Gods eschatological purpose with the whole of creation.

Secondly, the presence of a cosmic eschatology in the Old Testament support the hypothesis of this article in the sense that it validates the quest for consonance between the sciences. The eternal, triune God encompasses all of creation and nothing in the entire cosmos could be studied or revealed without acknowledging His supremacy and the gifts He bestowed on to creation (e.g. scientific endeavour). This was true even before the text of the Old Testament came into being. 
This comprehensive embracing of all of creation by the triune God comes to the fore not only in the prophetic literature, but also in the wisdom texts. Casarella (2001:6) reflects on the Lord's speech to Job in chapter 38-42 and affirms that: 'out of the whirlwind' is a song of praise to the artistry of the created world. However inexplicable the root of Job's anguish, his experience of God's withdrawal cannot be attributed to a clockmaker God ${ }^{19}$ Even in the face of natural evil, the mystery of cosmic redemption is quietly at work in nature's forces.' This observation is significant, especially in respect off the dialogue between science and religion and the pursuit of consonance. The reason be that the nature of God's agency and the meaning (if any?) of suffering in creation are dominant themes in the science/religious debate. This affirmation of a cosmic redemption (see also Rom 8:18-30) realized through the efficacy, not of a deist god, but the triune God, emphasizes that the ongoing preservation, as well as the eschatological purpose of the cosmos, involves a certain unity bestowed by the Creator. The Creator and Sustainer of the hippopotamus and the crocodile is also the loving Father who unites with Job in his suffering and distress. Job's suffering and triumph cannot be explained only in terms of destiny, or a scientific analysis of the historical factors which could influence his fate, or even his own mistakes. God's embracing presence in Job's crisis communicates an eschatological bearing of cosmic significance. The triune God is the foundation in the quest for consonance between the sciences.

At this point of the discussion the question beckons: what precisely is the relationship between the Creator and His creation then? Inevitably the term that regularly comes to the fore in recent debates about this subject is panentheism. ${ }^{20}$ It is not in the scope of this work to extrapolate on all the various permutations related to this phrase (which is one of its weaknesses), but a few remarks are important.

Brierley (2006:636) describes it as follows: 'Panentheism, from the Greek pan en theos, means 'all in God', and is commonly distinguished from (and conceived as the median between) classical theism, in which God

19 The clockmaker analogy alludes to the idea of deism, which is not what Job believed or experienced. Casarella use this analogy specifically to state the truth about God's encompassing compassion to an audience that may have deist delusions.

20 See Cooper 2006; Pieterse (2010:140). 
is essentially separate from the cosmos, and pantheism ('all [is] God).' Although prominent scholars (e.g. Clayton ${ }^{21}$ and Peacock ${ }^{22}$ ) explain God's agency in the world in a panentheistic fashion, the concept is also open to criticism. Thomas (2006:655) for example states that panentheism is often interpreted to mean primarily an intensification of divine immanence at the expense of divine transcendence. Polkinghorne (2004: xv) rejects classical panentheism because he believes it distorts the distinction between Creator and creation ${ }^{23}$. He states that the only benefit of a panentheistic account of God's agency might have is related to, '... an eschatological fulfilment, not a present reality' (Polkinghorne 1996b:168; 1998:16; Clayton 2003:215). In the New Testament, the substance of God's eschatological commitment becomes more visible.

\section{Cosmology and the New Testament}

\section{Cosmic Christology}

The Protestant Reformation of sixteenth century set the tone for a new interpretation and appreciation of Scripture, especially regarding the Personhood of Jesus and His sacrificial death as an atonement for man's spiritual corruptness. This new revelation about the essence of the incarnated Christ unfortunately also had a downside. The historical context and history of the church, as well as the prevailing doctrine, compelled the reformers to structure their theological reflections primarily around the salvation of the human soul ${ }^{24}$. Thus, God sent His only begotten Son to earth, for man to get eternal life. Christ's work was seen primarily as soteriological in nature with man's future on the line. This remark may

21 Clayton (1997:232-69).

22 Peacocke (1993:159-60).

23 For other points of contention: See Pieterse (2010:140-43).

24 The influence of and the literature about John Calvin is debated and studied by scholars throughout the ages. Regarding Calvin's view on cosmology, many scholars focus their research on Calvin's opinion of Copernicus' thesis (e.g. White 1980). In his article, John Calvin on the kingdom of God and Eschatology (2001), Van Wyk argues that although eschatology and cosmology are not completely absented in Calvin's writings, these subjects are underexposed. He states, '...but the question remains why Calvin gave so little attention to the new heaven and the new earth in the eschatological design of his main work. His thoughts were more "heavenly" than "earthly" and evoked the issue of Platonic influence' (Van Wyk 2001:203). 
sound exaggerated, but Casarella (2001:20) states that Luther's famous distinction between theologiae gloriae and theologia crucis, albeit with a noble intent, unwittingly abetted the problem of modern a-cosmism. De Jong (1987:159) validates this comment from a historical point of view. Luther challenged the Catholic Church's beliefs regarding natural theology and the way knowledge about God is obtained. This quest unfortunately led to a diminished role associated with Christ's incarnation and His resurrection within certain spiritual communities. Conversely, Scripture reminds us that God had from the very beginning a cosmological intend which will culminate in an eschatological redemption for all of creation. Jesus as God incarnate is central in the redemptive process of all creation.

In John 1:1-5 we read that the eternal Word (Jesus Christ in Johannine theology) became flesh, and significantly: ' 3 . All things were made by him; and without him was not anything made that was made' (King James Bible 2016). In his commentary on the text Hendriksen $(1982: 71,72)$ states that John conveys that, (i) Christ Himself was not created, and (ii) that all things in the universe (multiverse?25) were created by Him as the Light and Life of creation. This 'Light giving principle', although not specified here, is also the source of general revelation! Incarnation is of cosmic importance. Bruner $(2012: 14,15)$ notes that this text wants to make it very clear that the Word was the agent of all God's creation. The Word was none other than God's eternal Son who became flesh in Jesus of Nazareth. - If this passage is treated in an authoritative manner, as Gods Word, it has certain hermeneutical consequences regarding the quest for consonance between the sciences. Firstly, it underlines the significant role Christ fulfils in all of creation. It does not change, whether it is believed or not. Secondly, it refutes scientism's claims and methodology which aims to explain the created order exclusively in terms of physical processes and lineage without the need for a creator. Thirdly, it reminds the Christian scholar that natural science (as opposed to scientism) should be viewed as a useful tool, created and enlightened by the God. This gift of ever increasing scientific knowledge may be beneficial in unpacking the glories of creation

25 See Tegmark (2003:40-51): The term multiverse is a scientific hypothesis which is popularized by e.g. publications such as Universe or multiverse (2010), and speculates that our universe may be one of several which came into being as an account of unique circumstances during Big Bang inflation. 
and ultimately glorify God. If natural science accept theology as an equal partner, consonance between the Biblical and scientific assessment of nature is not only possible, but a natural extension of the One common denominator in all of creation, Jesus Christ, God incarnate.

The apostle Paul elaborates further on the significance of God's revelation in and through Jesus of Nazareth. He is not only God incarnate, but His presence as the Son of God in creation is of cosmic magnitude! In Col 1:15-20 Paul reaffirms John's revelation about Christ's presence and His responsibility in the creative processes in nature. Verse $\mathbf{1 7}$ illuminates this work of Christ even further: 'And he is before all things, and by him all things consist '(King James Bible 2016). Paul reminds his readers that the cosmic Christ is providentially active and indispensable for the physical and material kinesis of the natural order. ${ }^{26}$ The consequences of this statement led Helyer (1994:246) to declare that the incarnation of the Eternal Son of God in the man Jesus of Nazareth is nothing less than awe-inspiring, breath-taking and mind-boggling. Furthermore, Gibbs (1971:466) verifies that: '...this cosmic Christology, far from being a late addendum, belongs to the core of the Pauline concept of the Lord, no less than does theology of the cross. Both Paul's way of thinking about the Lord's cosmic work and what he wrote about it were integral to his Christology.' This insight is important regarding the quest for consonance. It reaffirms the fact that God had from the very beginning a broader focus than mere the saving of man's mortal sole. In addition, soteriology and cosmology does not exclude one another. To the contrary, Christ's all-encompassing presence in creation indicates an eschatological future which envelopes all of creation

Theological reflection unfortunately did not always appreciate the value of this vital insight. Casarella (2001:19) points out that in the Christian tradition, especially in the early church, the cosmic Christ was, '...preeminently personal, intimately involved with human subjectivity and history'. This immanence in and through transcendence unfortunately developed into impersonal arguments to set theism above the hypothesis of modern science ${ }^{27}$ This threat that natural science presented to Scriptural

26 See Pieterse 2012; See also McWilliams 1998.

27 See Buckley (1987: 363). The author highlights the Catholic responses to e.g. Newton and Descartes; in the debate between the sciences some scholars use the same kind of 
authority led some theologians to resort to philosophical reasoning instead of Biblical confession. Ironically, '... in that process, theistic proofs came to share a common starting point with the innovations associated with the new science of nature' (Casarella 2001:19). Subsequently, the cosmic Christ of Col. 1 transformed into a cold and unreachable deity.

The significance of Christ's dominion over all of creation is developed even further in Paul's letter to the Ephesians. In chapter 1 verse 10 he writes: 'That in the dispensation of the fullness of times he might gather together in one all things in Christ, both which are in heaven, and which are on earth; even in him:' (King James Bible 2016). This verse explains the importance of Christ in clarifying the content of the 'mystery'( $\mu v \sigma \tau$ ' $\rho\left\llcorner v^{28}\right)$ of God's will. Hendriksen (1972:85) argues that per verses 20-23 the fullness of times is the period which started with Christ's resurrection and will be concluded upon His glorious return. In this time, the substance of the mystery is revealed through the illumination of the Spirit. The essence of Paul's message is that, '... literally everything spiritual and everything material, has now been brought under Christ's rule' (Hendriksen 1972:86). Casarella (2001:8) makes it clear that neither the prologue to the gospel of John, nor Colossians 1:14-20, nor Ephesians 1:3-10 refer to a creative principle that is above rather than within the world. The texts confirm that: ...'the cosmic balance relies not on purely inner-worldly forces.' This insight is realized through faith alone. A statement which can hold up against scientific rigor, if scholars are brave enough to give credit to faith's foundational importance in natural science.

The revelation about Christ's absolute dominion has certain benefits regarding consonance. For example, it becomes clear that Gilkey's ${ }^{29}$ famous two language theory, concerning the relationship between the sciences, although structurally sound, is not entirely appropriate. The reason be that Christ's work could not be limited to personal or existential issues.

reasoning. For example, see Wildman (2008: 146) - the 'problem of evil' and suffering in creation leads Wildman to view God more as an Ontological reality and not the Personal Father with whom man can communicate.

28 The secret counsels which govern God in dealing with the righteous, which are hidden from ungodly and wicked men but plain to the godly. (Strong's Concordance 2016).

29 See Gilkey (1985:49-52) - Science' focus is public knowledge, whereas theology primarily ask questions of a personal and existensial manner. 
This is also true of other attempts which seek to keep natural science and theology in two separate bays. However, a convergent approach to the sciences (as previously cited) is absolutely essential for dialogue and possible consonance between theology and the natural sciences. Why? It relates to two possibly contrasting outlooks that modern cosmology and theology portrays for the future of the cosmos.

\section{Modern cosmology and biblical eschatology}

One of the challenges consonance faces is a consensus about the future of the universe and ultimately life itself. Russel (Southgate 1999) makes it clear: 'Concerning eschatology there seems to be no consonance - scientific cosmology predicts that the universe will end in a state devoid of structure or meaning; Christianity cherishes a final hope of redemption.' He calls this dilemma, dissonance. Russel's pessimistic view is well founded. One of the consequences of 'Big bang' ${ }^{30}$ cosmology is a very specific assessment of the way the physical universe will behave in the future. Polkinghorne (2004:144; 1996c:162) underlines the final futility of the physical universe either as a collapse back into a 'Big Crunch', or a steady expansion and cooling forever. ${ }^{31}$ This is due to the Second Law of thermodynamics ${ }^{32}$ which states that entropy (disorder) either increases or stays the same in a closed system (Ferreira 2003:307). Does this spell the end for consonance and dialogue between theology and natural science?

Quite the opposite, the New Testament also depicts initially a dark picture for the earth and life itself. The evangelists, Matthew and Luke, record the prophecies of Jesus regarding the end times respectively in chapters 24 and 21. In Revelation 20 John testifies about the circumstances surrounding

30 Although the hypothesis about the/a 'Big bang' is still contested within certain spiritual communities, it is widely accepted within the main stream scientific community. This recognition is based on the model of inference to the best explanation which states that some hypothesis could never be proved or disproved due to unique circumstances. The hypothesis is accepted on the basis that it explains a wide range of data more clearly than any other competing theory at the moment.

31 Recent research may suggest a speeding up of the universe due to some unknown mass. Dark matter may be the answer, but it is not clear now. Other theories speculate that the birth of the universe was due to a quantum fluctuation which could replicate itself infinitely. Nevertheless, all hypothesis suggests an impersonal future without real hope for 'mortal' man.

32 The second law of thermodynamics (2001). 
this final judgement as verse 11 states, 'And I saw a great white throne, and him that sat on it, from whose face the earth and the heaven fled away; and there was found no place for them '(King James Bible 2016). Although the exegesis of Revelation is a point of contention amongst different religious communities, the events unfolding now is quite clear. The reality of the 'earth and heaven' as we know it changes completely! Mounce $(1990: 364,365)$ affirms that this verse may only be poetic imagery: '...although it may be understood literally as the dissolution of the universe as we know it in preparation of the new heaven and earth...Whether it (the universe) simply passes away or is melted by fire (2 Peter 3:10-12) is of minor import.' - The point is that the physical universe will end through God's judgement, and a new creation will arise.

Consequently, could there possibly be a certain consonance between modern cosmology's assessment and John's vision of the things to come relating to an initial apocalypse with little hope for the future? I believe so. This proposal does not contain any references of a temporal nature, but is consistent about the future of the known and unknown cosmos. Consonance is not attained by weighing up the current scientific knowledge about the universe (which is more comprehensive), against the limited insight of the New Testament faithful. Consonance is found in an impending disaster with cosmic repercussions portrayed by ancient texts, as well as modern scientific understanding.

This initial pessimistic vision of the future remarkably also exhibits a coherence with events directly following Christ's brutal death. Luke 24: 17,18 describes the despondent attitude of the two friends travelling to Emmaus after Jesus died. It seems that all hope for the future was lost. John 20:13 depicts the same despair when Mary Magdalene weeps at the tomb because the Saviour and all His promises about the future seemed to be futile. The crucifixion of Jesus left His followers and their hope for the future in a state of disarray. In his commentary on Luke, Geldenhuys (1965:612) mentions the, '...unutterable grief and inability to comprehend of what had occurred...' of Jesus' followers. This was the reason that they watched the crucifixion only from a distance. However, it was not the end!

The Resurrected Christ is none other than the cosmic Christ of Colossians 1. He is also the Kenotic Christ that chose in His immanence to suffer with 
and for creation as Paul reminds his readers in Philippians 2: 2-11 and Romans 8. It is an era of renewal, not only for the saints, but for the whole cosmos. I believe it is at this point that theological boldness is necessary by affirming that the scientific view of a futile universe, albeit correct, is not the complete and only picture. The hypothesis' about a future universe as presented by main stream modern cosmology and theoretical physics, brilliant and creative as it may be, falls prey to reductionist ${ }^{33}$ assumptions. Reality is multi-layered and in need of a more holistic explanation.

\section{Cosmology in the presence of the resurrected and exalted Christ}

The first indication of a cosmic renewal may be found in the narrative about the transfiguration of Christ (Mk 9:2-13; Mt 17:1-13; Lk 9:28-36). Casarella $(2001: 30,31)$ notes, 'At stake here is more than the divinity's self-revelation...the vision of the transfiguration becomes the basis for a new form of perception and a new mode of existence.' At that moment, the possibility of a new unity between matter and Spirit became reality. A reality actualized in the resurrection and ascension of Jesus Christ. Through His resurrection every speck of creation received an eschatological hope of renewal and transformation. Haught (2007:174) notes that: '.. it is by anticipating nature's essential, though not yet actualized, eschatological aliveness ... that theology will be able to arrive at an accurate reading of the cosmos. Such an approach to understanding the resurrection will have the additional advantage of not conflicting in any way with natural science'.

Therefore, although from a material perspective the futility of the universe might be a foregone conclusion per scientific data, the certainty of eschatological hope as embodied by Christ should alter the cold and impersonal vision of the future so eagerly communicated by natural and theoretical science. Kärkkäinen $(2015: 203,205)$ reminds us that Christian eschatological hope encompasses the whole of creation and indeed overcomes entropy! In the quest for consonance between the sciences a

33 See Polkinghorne 2002 for the different types of reductionism. In general, the term describes the belief that a complex system is nothing but the sum of its parts. An account of it can be reduced to accounts of individual constituents. An example of reductionism is found in Dennett's work, Darwin's dangerous idea (1995), where he concludes that, 'all forms of complexity in nature derive from evolutionary processes with no regard for any type of design or designer (Dennett 1995:317).'; see also: (Pieterse 2015). 
Trinitarian vision may enrich the debate, as John Haught (2007:163) eloquently summarizes: 'God the Son, through the incarnation, concretizes the divine descent in nature and history, gathering all things corporeally to himself and handing them over to the Father, again by the power of the Spirit.'

\section{Articles of faith and consonance}

Any theological reflection concerning consonance would be incomplete if the relevant paragraphs contained in the articles of faith are not considered. The first task is to identify which of the myriad Confessions of believers and the church should be included in this endeavour. There are two aspects which assisted the author. First, from a numerical point of view the scope of this/any article is limited. Secondly, as a reformed theologian I am biased to choose two confessions I believe played an important role in reformed theology. Therefore, I would restrict the analysis to the Belgic confession (1561) and the Heidelberg catechism (1563).

Article 2 of the Belgic confession states:

How God makes Himself known to us - we know Him by two means: First, by the creation, preservation, and government of the universe; which is before our eyes as a most beautiful book, wherein all creatures, great and small, are as so many letters leading us to perceive clearly the invisible things of God, namely, His eternal power and deity, as the apostle Paul says (Rom 1:20). All these things are sufficient to convict men and leave them without excuse. Second, He makes Himself more clearly and fully known to us by His holy and divine Word as far as is necessary for us in this life, to His glory and our salvation. (Ps 19:1-4, Ps 19:7, 8; 1 Cor 1:18-21) (Bouwman 2015).

In his commentary on De Bres's confession Bouwman (2015) says: 'By creating, by what He did and by the way He did it, God revealed something of Who He is...God let's all that He created continue to exist. God allows reproduction among living organisms. God is not remote from anything that occurs. He is actively in control of all that happens in His creation'. This statement reaffirms the conviction of Paul in the New Testament 
regarding the incarnated Christ (Article 18), as well as the essence of the Old Testament Scriptures previously cited in this study. The created order so intimately studied by natural science, is intertwined with God's agency. His upholding, preservation, and governance (Article 13) of the cosmos is self-evident through the eyes of faith and the illumination of Scripture by the Holy Spirit. This statement is clear for any believer in the triune God because, '... the primary author of the Bible is also the author of the book of nature' (Riddlebarger 2015). Although this testimony is selfevident for believers, it may not be the case for everybody. Nonetheless, it sets up a challenge to secular society to re-examine common held beliefs. In his exposition of Article 2, Van den Brink (2011: 285-288) distinguishes between three competing interpretations ${ }^{34}$ of the article regarding the different sources through which man receives true knowledge about the triune God. Although God's redemptive revelation through Scripture remains the primary source of knowledge, it may be possible (in line with the post-reformational seventeenth century Reformed theology) to confess that God revealed some of his glory and majesty in creation, but that this signal is never picked up, distorted, or even misused by man. Therefore, creation cannot function as a source of knowledge about God. Is it possible then that the splendours of God throughout creation could be highlighted today through scientific means by faithful Christian scientists? For sure! Reformation theology did not have access to the wonders of the universe, the complexity of quantum physics, or the marvels of the human body. Consonance is attained by acknowledging that man is committed and cognitively equipped (Erasmus 2014:6) to study the 'most beautiful book' of nature, and through Scriptural revelation the true admiration of nature is attained. In addition, Erasmus (2014:4) affirms that there is a unity in truth between nature and Scripture. This unity is mutually dependent, with the eschatological Christ as the Creator and Redeemer of the cosmos at its centre.

34 1. We know God primarily through Scriptural revelation, and through the 'spectacles' of the Word we find traces of God in creation; 2. A post - Barthian interpretation reads the article entirely based on the very first word 'we'. Knowledge about God through creation would be entirely a faith based knowledge, because we refer to the faithful; 3 . The option in the text. 
A few introductory remarks about the Heidelberg catechism (HC) and its relevance to this research. In his article, The doctrine on God, as demonstrated and confessed in the Heidelberg Catechism, Coetzee (2013) focus briefly on the relationship between God and the cosmos as confessed in the catechism. The author differs in opinion regarding his stance on evolution ${ }^{35}$ and the possibility of God's employment thereof in creation, but certain remarks about the $\mathrm{HC}$ in his research are important. He noticed that: 'The HC (therefore) does not have a systematic doctrine of God. Different aspects of the doctrine are found throughout' (Coetzee 2013). This insight is relevant. This lack of a systemic approach does not mean that the doctrine about God was not important. To the contrary. Coetzee (2013) observed that the doctrine of the Trinity appears as a golden thread running through the $\mathrm{HC}$ and that the emphasis is generally on what God in the Trinity does. Simultaneously, there is the 'unmistakable appearance of evidence' of the Christocentric nature of the Catechism ${ }^{36}$.

The doctrine about the providence of God is dealt with in Lord's Day 10 (question and answer $27 \& 28$ ) and states:

27. Q. What do you understand by the providence of God?

A. God's providence is his almighty and ever present power, 1 whereby, as with his hand, he still upholds heaven and earth and all creatures, 2 and so governs them that leaf and blade, rain and drought, fruitful and barren years, food and drink, health and sickness, riches and poverty, 3 indeed, all things, come to us not by chance 4 but by his fatherly hand. 5

1. Jer 23:23, 24; Acts 17:24-28. 2. Heb 1:3. 3. Jer 5:24; Acts 14:15-17; Jn

9:3; Prov 22:2. 4. Prov 16:33. 5. Mt 10:29.

35 See: Coetzee (2013) states that by accepting the theory of evolution, one denies by implication God's creation and providence. It is a simplistic remark, because evolutionary theory is diverse in nature and explanation. It is quite possible that God's providence included evolutionary development (Pieterse 2015).

36 Coetzee bases his argument on the work of Verboom (2012) and Korn (1963). For example, Korn (1963:94) states: 'The HC is about the acts of God in and through the person and work of Jesus Christ'. 
28. Q. What does it benefit us to know that God has created all things and still upholdsthem by his providence?

A. We can be patient in adversity, 1 thankful in prosperity, 2 and with a view to the future we can have a firm confidence in our faithful God and Father that no creature shall separate us from his love; 3 for all creatures are so completely in his hand that without his will they cannot so much as move. 4

1. Job 1:21, 22; Ps 39:10; Jas 1:3. 2. Deut 8:10; 1 Thess 5:18. 3. Ps 55:22;

Rom 5:3-5; 8:38, 39. 4. Job 1:12; 2:6; Prov 21:1; Acts 17:24-28.'

In his article, 'The Theology of Providence', Fergusson (2010:262) observed that the explanation of God's providence in the catechism as presented in the answers above, seem to be deterministic in nature. For the casual reader, it may seem that the sovereign God controls creation in such a manner that there is little room for secondary causes ${ }^{37}$ or the creative powers bestowed on nature. Fergusson argues that this deterministic line of thought, although Biblically sound, could be traced to Stoic philosophy and its influence on the religious and social mindset of the early Christians. Consequently, God's providential agency in the world, per the early Christian theology (and resonated by the HC and Reformers e.g. Calvin) seem to leave little scope for creative novelty. Unfortunately, '... it led to an overbearing determinism that leaned too far toward an acquiescence with the way things were, (and) ignored biblical themes of struggle and resistance' (Fergusson 2010:265).

The quest for consonance provides the opportunity to draw attention to recent theological and scientific research ${ }^{38}$ relating to the fabric of creation. Whereas the above confessions regarding providence accentuate God's reservatio and gubernatio, it falls short in explaining what precisely

37 In this context, secondary causes refer also to e.g. bottom up and whole/part theories of Divine agency.

38 In chapter 6 of his excellent work, Creation and humanity, Kärkkäinen (2015:102) reflects on the important shift from substance ontology aligned with dualisms of various sorts, to relationality and holistic explanations. This change in perspective is demonstrated by the ongoing effort to identify a comprehensive theory of everything in the physical world. From a theological perspective, the rediscovery of perichoresis and a Trinitarian vision is beneficial to the debate. 
reformed theology understands under concursus. From the very beginning (Gen 1:28) God endowed man and creation with the necessities to be cocreators. This gift does not in any way diminish God's sovereign rule or transform man or creation into a demi-gods. To the contrary, it enriches the natural order and brings glory to God who in His wisdom created a dynamic cosmos in which He is ever present - Psalm 139. The HC is true in portraying God as the heart and soul of creation, but the confessions need to be elaborated further. Fergusson (2010:275) states that, 'A Trinitarian theology of providence might usefully assist us in this respect by presenting it in ways that are not dominated by a single model appropriated to the first person. Both Son and Spirit participate intimately in the work God's particular providence'.

A Trinitarian theology emphasizes what the OT and NT confess about the nature of God's agency in and through Christ as underlined previously. It does not diminish in any way Ursinus' original thoughts about providence as Coetzee (2013) highlights: 'Just as nothing could have come into being unless God created all things in like manner, nothing can maintain its existence for one moment unless God keeps it by his providence and management' Ursinus (1886:196-197) ${ }^{39}$. This all-encompassing presence of God in creation and the creative novelty of the Spirit is key in the quest for consonance between the sciences. Although scientific means is not capable to prove, or sometimes even willing to accept this faith based proposal, its reality cannot be ignored ${ }^{40}$. Consonance might be attained through the acknowledgement from believers that responsible scientific endeavor may reveal areas in the natural order where creative novelty (as an instrument of God's creatio continua) is possible and likely to be present. Simultaneously, natural science should acknowledge that reductionism leads to a deprivation of knowledge, and that Christian confessions (e.g. $\mathrm{HC}$ ) and Biblical testimonies about the agency of the triune God enriches the mosaic of creation. Consonance is not possible if theology's task is only

39 Ursinus, Z., 1886, Verklaring op den Heidelbergschen Catechismus, translated by C van Proosdij, Zalsman, Kampen.

40 The fallacy of scientism and reductionism is well documented in the debate between the sciences, e.g.: Haught (2012:103). 
to provide a God of the $\operatorname{gaps}^{41}$ in response to the lack of an appropriate scientific hypothesis.

\section{Conclusion}

The author stated in the introduction that an attempt will be made to prove through theological reasoning why consonance between the sciences is Biblically, as well as confessional sound. This endeavour is grounded on the premise that the Biblical confession regarding Christ as stated in the New Testament (e.g. Colossians 1, John 1) and echoed in the Confessions of the church has important implications for the current dialogue between the sciences. Throughout this article, various arguments were introduced to explain the all-inclusive agency of the triune God along with the prominence of Christ as the cosmological focal point through which an eschatological renewal of all creation comes about. Fergusson' (2010:276) concludes that: 'The work of salvation determines not only the community of the faithful but the whole cosmos, and this must include the natural world and our rootedness in it. To that extent, we can rejoice in the regularities of nature and the rhythms of life as echoes of God's goodness, those phenomena that have often been classified as works of general providence'.

\section{Bibliography}

Barbour, IG 1990. Religion in the age of science. London: SCM Press.

Barrow, J 2007. New theories of everything. New York: Oxford University Press.

Bouwman, C 2015. 'Notes' on the Belgic confession. [Online]. Available: http://www.spindleworks.com/library/bouwman/belgic/ART02.htm [Accessed: 06/12/16].

Brierley, MW 2006. The potential of panentheism for dialogue between religion and science. In P Clayton, et al. (ed.), The Oxford handbook of religion and science, 635-51. Oxford: University Press.

41 This phrase commonly describes the delusion that science is the only and purest way in attaining true knowledge and that theology's only contribution is to provide a God hypothesis for areas where scientific research at this moment is limited. 
Bruner, FD 2012. The Gospel of John - a commentary. Grand Rapids: Eerdmans.

Buckley, M 1987. At the Origins of Modern Atheism. New Haven: Yale University Press.

Carr, B 2010. Universe or multiverse, 1 edition. Cambridge: Cambridge University Press.

Casarella, P 2001. Waiting for a cosmic Christ in an uncreated world.

Communio 28 (Summer) Communio: International Catholic Review, $1-35$.

Childs, BS 1985. Old Testament theology in a canonical context. London: SCM Press.

Clayton, P 1997. God and contemporary science. Grand Rapids: Eerdmans.

Clayton, P 2003. God and the World. In Vanhoozer, K J (ed.), The

Cambridge Companion to Postmodern Theology, p.203-18. Cambridge: University Press.

Coetzee, FC 2013. The doctrine of God/Heidelberg catechism. [Online]. Available: http://www.scielo.org.za/scielo.php?script=sci_arttext\&pid=\$230508532013000200005\&lng=en\&tIng=en [Accessed: 08/12/16]

Conradie, E 2009. Pneumatologiese kantaantekeninge rondom eietydse diskoers oor God se handelinge in die wêreld, gelewer tydens die konferensie van die Dogmatologiese werksgemeenskap van SuidAfrika. Universiteit van Stellenbosch, 22-26 Junie.

Creationism. [Online]. Available: https://www.merriam-webster.com/dictionary/ creationism [Accessed: 10/07/17].

Deist, F, W Vorster (ed.) 1987. Woorde wat ver kom. Die literatuur van die Ou Testament (deel 1). Kaapstad: Tafelberg Uitgewers.

Cooper, JW 2006. The other God of the philosophers: from Plato to the present. Grand Rapids: Baker Academic.

Dennett, D 1995, Darwin's dangerous idea. Simon \& Schuster: New York, NY.

De Jong, OJ 1987. Geschiedenis der kerk. Nijkerk: Callenbach. 
Erasmus, J A 2014, 'Artikel 2 van die Nederlandse Geloofsbelydenis as Geloofsvooronderstelling in die gesprek tussen wetenskap en geloof', In die Skriflig 48(1), Art. \#1757, 8 pages. http://dx.doi. org/10.4102/ids. v48i1.1757

Fergusson, D 2010. The doctrine of providence. [Online]. Available: https://www.researchgate.net/profile/David_Fergusson5/publication/258197925_ The_Theology_of_Providence/links/54b7a5780cf2e68eb2803712.pdf [Accessed: 08/12/16]

Ferreira, J 2003. Cosmological and Biblical eschatologies: Consonance or dissonance. In Evangelical Review of Theology 27:4, p. 306-17.

Fulljames, P, Stolberg, T 2000. Consonance, Assimilation or Correlation? Science and Religion Courses in Higher Education. Science \& Christian Belief, Vol 12, No. 1, P. 35-46.

Gannon, M 2015. Science and religion can coexist. [Online]. Available: http://www.livescience.com/50162-most-evangelical-christians-dont-feel-hostile-toscience.html [Accessed: 25/01/16].

Geldenhuys, J N 1965. Commentary on the Gospel of Luke. London: Lowe and Brydone.

Gerhart, M, Russell, AM 1996. Mathematics, empirical science, and religion. In WM Richardson \& WJ Wildman (eds.), Religion and science. New York: Routledge. 121-28.

Gibbs, JG 1971. Pauline cosmic Christology and ecological crisis. Journal of Biblical Literature, 90 no 4 Dec, p 466-479

Gilkey, LB 1985. Creationism on trial. Minneapolis: Winston Press.

Gunton, C 2002. The Spirit moved over the face of the waters: The Holy Spirit and the created order. International Journal of Systematic Theology July 4 (2): 190-204.

Haught, JF 1995. Science and religion: from conflict to conversation. New Jersey: Paulist Press.

Haught, JF 2007. Christianity and Science: Toward a Theology of Nature. Maryknoll, NY: Paulist Press.

- 2012. Science and faith: A new introduction. New York/ Mahwah, New Jersey: Paulist Press. 
Hawking, SW, Mlodinow L 2010. The Grand Design. New York: Bantam books.

Heidelberg catechism 2010. [Online]. Available: http://www.heidelbergcatechism.com/en/lords-days/10.html [Accessed: 15/12/16]

Helyer, LL 1994. Cosmic Christology and Col 1:15-20. In JETS 37/2 (June), p. 235-246.

Hendriksen, W 1972. New Testament commentary, Ephesians. Chatham: W\&J Mackay Limited.

- 1982. New Testament commentary, John. Southampton: The Camelot Press.

Holy Bible, 1991. Good news edition. Goodwood: National Book Printers.

Horgan, J 2005. Clash in Cambridge. [Online]. Available: https://www. scientificamerican.com/article/clash-in-cambridge/ [Accessed: 14/01/16]

Hughes, AL 2012. The folly of scientism. [Online]. Available: http://www.csiindia.org/document_library/Folly_of_Scientisme988.pdf [Accessed: 14/02/17]

Kärkkäinen, VM 2015. Creation and humanity: a constructive Christian theology for the pluralistic world. Grand Rapids, Michigan: Eerdmans.

King James Bible 2016. [Online]. Available: http://www.kingjamesbibleonline.org/ John-Chapter-1/ [Accessed: 22/09/16]

Korn, WE 1963, Die Lehre von Christi Person und Werk. In L. Coenen (ed.), Handbuch zum Heidelberger Katechismus. Neukirchener Verlag, Neukirchen. 91-104

Lennox, JC 2007, God's undertaker: Has science buried God? Oxford: Lion Hudson.

Michaud, AM 2010. John Haught - finding consonance between religion and science. Zygon, vol. 45, no. 4 (December), 905-20.

McGrath, AE 2004. On writing a scientific theology: A response to Ross H McKenzie. Dialogue1: Theology and Physical Science 56/4: 255-59

McWilliams, W 1998. Christic Paradigm and Cosmic Christ: Ecological Christology in the Theologies of Sallie McFague and Jürgen Moltmann. In Perspectives in Religious Studies, 25 no 4 Winter, 341-55. 
Moltmann, J 1990. The Way of Jesus Christ: Christology in Messianic Dimensions, translated Margaret Kohl. Minneapolis: Fortress. 46-48.

Moltmann, J 1996. The Coming God: Christian Eschatology, translated Margaret Kohl. Minneapolis: Fortress.

Mounce, RH 1990. Revelation. Grand Rapids: Eerdmans.

Pannenberg, W 1994. Systematic theology, translated Geoffrey W Bromiley. Grand Rapids: Eerdmans.

Peacocke, AR 1993. Theology for a scientific age: being and becomingnatural, divine, and human $2^{\text {nd }}$ edition. Minneapolis: Fortress Press.

Pieterse, AC 2010. 'Die God-wêreld-verhouding in die kontemporêre geloof-wetenskap- dialoog: Die bydrae van JC Polkighorne. D.Thproefskrif in die Department van Dogmatologie, Universiteit van die Vrystaat.

- 2012. Pneumatologie as dinamiese modus vir deurlopende goddelike handelinge in komplekse sisteme. In Journal for Christian scholarship $49(3 ; 4), 87-111$.

- 2015. Ecclesia Reformata semper Reformanda: A convergent approach to science and theology may reinforce Scriptural authority. In Verbum et Ecclesia 36(1), Art. \#1420,12 pages. http://dx.doi.org/10.4102/ve.v36i1.1420

Peters, T 1997. Theology and natural science. In The Modern Theologians, edited D Ford. Oxford: Blackwell.

Polkinghorne, JC 1987. Creation and the Structure of the Physical World. Theology Today 64 (1), 53-68.

- 1996a. Chaos theory and Divine action. In WM Richardson, WJ Wildman (eds.), Religion and science. New York: Routledge. 243-251.

- 1996b. Scientists as Theologians. London: SPCK.

- 1996c. The faith of a physicist. Princeton: Fortress Press.

- 1998. Belief in God in an age of science. New Haven \& London: Yale University Press.

- 2002. Reductionism. [Online]. Available: http://inters.org/reductionism [Accessed: 18/11/16]

- 2004. Science and the trinity: the Christian encounter with reality. Yale: University Press. 
- 2005. The continuing interaction of science and religion. Zygon 40 (1) Mr: 43-50.

Popper, K 2002. The logic of scientific discovery (Routledge classics) $2^{\text {nd }}$ edition. New York: Routledge.

Riddlebarger 2015. A Commentary on the Belgic Confession. [Online]. Available: http://kimriddlebarger.squarespace.com/a-commentary-on-the-belgiccon/3\%20edited\%20\%20by\%20two\%20means\%20riddleblog.pdf [Accessed: $06 / 12 / 16]$

Southgate, C 1999. Consonances between Science and Religion. [Online]. Available: http://www.counterbalance.org/ghc-outl/conso-body.html [Accessed: 23/07/15]

Stenmark, M 2010. Ways of relating science and religion. In Harrison, P (ed.), The Cambridge companion to religion and science. Cambridge: University Press. 278-95.

Strong's Concordance 2016. Strong's Greek words 3466. Mustérion. [Online]. Available: http://biblehub.com/greek/3466.htm [Accessed: 07/10/16]

Tegmark, M 2003. Parallel universes. Scientific American 288(5):40-51. [Online]. The second law of thermodynamics 2001. Available: http:// www.entropylaw.com/entropy2ndlaw.html [Accessed: 07/03/17].

Thomas, OC 2006. Problems in panentheism. In Clayton, $\mathrm{P}$ et al. (ed.), The Oxford handbook of religion and science. Oxford: University Press. 652-64.

Tipler, F 1994. The physics of immortality. New York: Doubleday.

Torrance, TF 1969. Theological science. Oxford: University Press.

- 2005. The ground and grammar of theology: consonance between science and theology. Bloomsbury T\&T Clark: Edinburgh/New York.

Ursinus, Z 1886. Verklaring op den Heidelbergschen Catechismus, translatede $\mathrm{C}$ van Proosdij, Zalsman: Kampen.

Van den Berg, ML 2010. 'What general revelation does (and does not) tell us', Perspectives on Science and Christian Faith 62(1), 16-24.

Van den Brink, G 2011. A most elegant book: the natural world in article 2 of the Belgic confession. Westminster theological journal 73, 273-91. 
Van Huyssteen, JW 1998. Duet or dual? Harrisberg: Trinity Press.

Van Selms, A 1984. De prediking van het oude testament, Genesis, $4^{\text {th }}$ edition. Nijkerk: Uitgeverij Callenbach.

Van Wyk, JH 2001. John Calvin on the kingdom of God and eschatology, In die Skriflig 35(2) p.191-205.

Veenhof, J 2006. Nature and grace in Bavinck. [Online]. Available: http:// digitalcollections.dordt.edu/cgi/viewcontent.cgi?article $=1466 \&$ context=pro_rege\&sei-re dir=1\&referer=http\%3A\%2F\%2Fscholar.google.co.za\%2Fscholar\%3Fstart\%3D10\%26q\% 3DRoman\%2Bcatholick\%2Bdualism\%2Bnature\%2Band\%2Bgrace\%26hl\%3Den\%26as_ sdt\%3D0\%2C5\#search=\%22Roman\%20catholick\%20dualism\%20nature\%20grace\%22 [Accessed: 17/02/17]

Verboom, W 1996. De theologie van de Heidelbergse Catechismus: twaalf thema's: de context en de latere uitwerking. Zoetermeer: Boekencentrum.

Waltke, BK 2007. An Old Testament Theology: An Exegetical, Canonical, and Thematic Approach. Grand Rapids, Michigan: Zondervan.

White, R 1980. Calvin and Copernicus: the problem reconsidered. Calvin Theological Journal 15 (2) N, p.233-43.

Wildman, WJ 2008. The Divine action project, 1988-2003. In Russel, RJ et al. (ed.), Scientific perspectives on Divine action. Vatican City State: Vatican Observatory Publications. 133-76.

Wolterstorff, N 1988. Reason within the Bounds of Religion (PBK). 2 edition, Grand Rapids: Eerdmans.

Worrall, J 2004. Science Discredits Religion. In M Peterso and R Vanarragon, (eds). Contemporary Debates in Philosophy of Religion. Oxford: Blackwell Publishing. 59-71.

Wright, NT 2011. Mind, Spirit, Soul, and Body. [Online]. Available: http:// ntwrightpage.com/Wright_SCP_MindSpiritSoulBody.htm [Accessed: 14/06/16] 